\title{
The effects of an osmoregulator, carbohydrates and polyol on maturation and germination of 'Golden THB' papaya somatic embryos
}

\author{
KRISTHIANO CHAGAS ${ }^{1}$, JAMILE L.D. CIPRIANO ${ }^{2}$, JOSÉ CARLOS LOPES ${ }^{3}$, EDILSON \\ R. SCHMILDT ${ }^{4}$, WAGNER C. OTONI ${ }^{1}$ and RODRIGO S. ALEXANDRE ${ }^{5}$ \\ ${ }^{1}$ Laboratório de Cultura de Tecidos Vegetais/BIOAGRO, Departamento de Biologia Vegetal, Universidade \\ Federal de Viçosa, Campus Universitário, Avenida Peter Henry Rolfs, s/n, 36570-900 Viçosa, MG, Brazil \\ ${ }^{2}$ Instituto Federal de Minas Gerais, Campus Sabará, Avenida Serra da Piedade, \\ 299, Morada da Serra, 34515-640 Sabará, MG, Brazil \\ ${ }^{3}$ Laboratório de Análise de Sementes, Departamento de Agronomia, Centro de Ciências Agrárias \\ e Engenharias, Universidade Federal do Espírito Santo, 29500-000 Alegre, ES, Brazil \\ ${ }^{4}$ Departamento de Ciências Agrárias e Biológicas, Centro Universitário Norte do Espírito Santo, Universidade Federal \\ do Espírito Santo, Campus Universitário, Rodovia BR-101 Norte, Km 60, 29932-540 São Mateus, ES, Brazil \\ ${ }^{5}$ Departamento de Ciências Florestais e da Madeira, Centro de Ciências Agrárias e Engenharias, Universidade Federal \\ do Espírito Santo, Avenida Governador Lindemberg, 316, Centro, 29550-000 Jerônimo Monteiro, ES, Brazil
}

Manuscript received on December 27, 2017; accepted for publication on March 2, 2018

\begin{abstract}
This study evaluated the effect of osmoregulators and carbohydrates on the maturation and germination of somatic embryos of papaya 'Golden THB'. Cotyledon explants from papaya seedlings germinated in vitro on basal MS medium were cultured on somatic embryogenesis induction medium (IM) containing MS salts, myo-inositol, sucrose, agar and p-chlorophenoxyacetic acid. After 50 days, embryogenic calli were transferred onto maturation media (MM) for 45 additional days. For experiment 1, a MS-based medium supplemented with abscisic acid, activated charcoal and concentrations of PEG $6000(0 ; 40$; $50 ; 60$ and $\left.70 \mathrm{~g} \mathrm{~L}^{-1}\right)$ was used, whereas for experiment 2 malt extract concentrations $(0 ; 0.1 ; 0.2 ; 0.3$ and $0.4 \mathrm{~g} \mathrm{~L}^{-1}$ ) were assessed. The normal cotyledonary somatic embryos produced in experiment 2 were transferred to the germination medium (GM). The GM consisted of full-strength MS medium, sucrose, agar and was supplemented with myo-inositol at varying concentrations $(0 ; 0.275 ; 0.55$ and $0.825 \mathrm{mM})$. The PEG concentrations tested impaired the maturation of 'Golden THB' papaya somatic embryos. The $\mathrm{MM}$, supplemented with malt extract at $0.153 \mathrm{~g} \mathrm{~L}^{-1}$, promoted the greatest development of normal somatic embryos $\left(18.28 \mathrm{SE}\right.$ calli $\left.^{-1}\right)$, that is, two cotyledonary leaves produced $36.56 \mathrm{SE}$ calli ${ }^{-1}$. The supplementation with $0.45 \mathrm{mM}$ myo-inositol provided the highest germination percentage $(47.42 \%)$ and conversion to emblings.
\end{abstract}

Key words: Carica papaya L., malt extract, myo-inositol, polyethylene glycol.

Correspondence to: Rodrigo Sobreira Alexandre

E-mail: rodrigosobreiraalexandre@gmail.com 


\section{INTRODUCTION}

Papaya (Carica papaya L.), a tropical fruit crop, is produced in most tropical and sub-tropical countries, with India and Brazil accounting for $41.2 \%$ and $12 \%$ of world production, respectively (FAO 2012). In Brazil, 'Golden THB' is the main cultivar of the Solo group produced and exported. This cultivar has numerous advantages, such as the low plant height (2.0 to $2.5 \mathrm{~m}$ at 2.5 years of age), which facilitates pest and disease control and fruit harvesting; predominance of perfect hermaphrodite flowers and absence of carpelloidy and petandry; highly productive, with uniform, vigorous highly sanitary plants; uniform and pyriform fruits; lightor deep-yellow external coloration, orange to red pulp and firm texture (Feltrin Sementes 2009, Quintal et al. 2012).

Papaya is propagated by seeds and due to the limitation to identifying the sex in the seedlings, farmers plant at least three seedlings per pit for further sexing, which increases production costs and affects the development of hermaphrodite plants by competition for water, light and nutrients. As an alternative to these problems, the in vitro culture of papaya has the potential to be used on a commercial scale, by means of somatic embryogenesis (SE), producing synthetic seeds to be made available to the farmer.

Somatic embryogenesis is based on cell reprogramming through the pluripotent expression of somatic cells (Altamura et al. 2016); it is a morphogenetic pathway with great potential for massive propagation of various species (Isah 2016, Seifert et al. 2016). The pathway encompasses developmental stages, namely induction, maturation and germination, in which some regulatory substances, a such as growth regulators (auxins, cytokinins, gibberellins and abscisic acid), antioxidants (activated charcoal and polyvinylpyrrolidone), polyethylene glycol (PEG), malt extract (ME), and myo-inositol (MI).
In polyembryogenic cultures of Pinus sylvestris L., PEG, for example, provides the accumulation of the polyamines putrescine and spermine, which may be related to the specificity in the protection against stress (Muilu-Mäkelä et al. 2015). However, in Passiflora cincinnata, polyamines were not correlated with morphogenetic responses (Dias et al. 2010). ME stimulates the activity of hydrolytic enzymes (Kim et al. 2010) that facilitate the breakdown of starch into maltose (Jung et al. 2011). Maltose is the best carbohydrate source for the induction of somatic embryogenesis in Citrus sinensis L. Osbeck at concentrations of 37 and 75 $\mathrm{mM}$ (Castro et al. 2010). Inositol, most abundantly found in the form of MI, cis-1,2,3,4-trans-4,6cyclohexanehexol is a cyclic polyalcohol with an important role as a structural base for second messenger in eukaryotic cells such as inositol phosphates (IPn). The myo-inositol-1L-phosphate synthase (MIPS) catalyzes the conversion of D-glucose 6-phosphate to 1-L-myo-inositol-1phosphate. Inositol phospholipids play a vital role in membrane traffic and signaling pathways, storage and transport of auxin, phytic acid biosynthesis, cell wall biosynthesis, and production of stressrelated molecules (Abreu and Aragão 2007). MI also affects the production of $\mathrm{A}$ and $\mathrm{B}$ senosides (anthraquinone glycosides) in in vitro calli of Cassia angustifolia Vahl with important anticancer activity (Chetri et al. 2016).

Somatic embryogenesis has numerous advantages, including the production of thousands of embryos, synthetic seeds, and axenic plants identical to the mother plant. The induction of SE from juvenile tissues is preferable as these explants have the advantage of being more responsive and, therefore, can initiate the development of efficient protocols. In this sense, it is possible to produce embryogenic calli on a large scale and from them to isolate somatic embryos, many of which are maintained in vitro and a small amount are converted into plants. These plants, 
are acclimatized in the ex vitro environment and, after three to four months of age, the hermaphrodite plants are identified and kept. In this way, the hermaphrodite plants are traced to find identify the in vitro pro-embryogenic mass that served as the original source. This indicates that the remaining in vitro embryos are also hermaphrodite, which can be an efficient method to produce hermaphrodite papaya seedlings on a commercial scale.

In this context, the objective of this work was to establish an efficient protocol for maturation and germination of somatic embryos from cotyledonary leaves of 'Golden THB' papaya.

\section{MATERIALS AND METHODS}

\section{PLANT MATERIAL}

In vitro seed germination to obtain cotyledonary leaves to be used as an explant source for somatic embryogenesis was carried out at the Laboratório de Cultura de Tecidos Vegetais of Departamento de Ciências Agrárias e Biológicas of Universidade do Centro-Norte do Espírito Santo of the Universidade Federal do Espírito Santo (UFES), campus São Mateus, ES.

Seeds were removed from 'Golden THB' papaya at ripening stage 5 , with more than $75 \%$ of yellow skin, from a commercial crop at the "Vovô Délio" farm, in the municipality of São Mateus, ES. Seed sarcotesta or aril was removed with hydrated lime by friction in a polypropylene sieve and washed in tap water with neutral detergent. In a laminar flow hood, the seeds were incubated in $70 \%$ alcohol for $1 \mathrm{~min}$, followed by commercial sodium hypochlorite solution (2.5\%) (Teiú, Brazil) with three drops of Tween $-20^{\circledR}$ for 15 min and then treated with $50 \%$ hydrogen peroxide for $10 \mathrm{~min}$. Between each treatment, the seeds were washed three times with distilled, autoclaved water.

After surface-sterilization, seeds were inoculated into $25 \times 150 \mathrm{~mm}$ test tubes containing $10 \mathrm{~mL}$ of full strength MS medium (Murashige and Skoog 1962), myo-inositol (0.55 mM), sucrose $(87.5 \mathrm{mM})$ and $\operatorname{Vetec}^{\circledR} \operatorname{agar}\left(8 \mathrm{~g} \mathrm{~L}^{-1}\right)$. The $\mathrm{pH}$ of the medium was adjusted to $5.7 \pm 0.1$ before agar addition and then autoclaved for $20 \mathrm{~min}$ at $121{ }^{\circ} \mathrm{C}$ and $1.05 \mathrm{~kg} \mathrm{~cm}^{-2}$ pressure.

Seeds were kept in BOD (Biochemical Oxygen Demand; Eletrolab ${ }^{\circledR}$ ) with alternating temperature of $20-30{ }^{\circ} \mathrm{C}$, in the dark. After tegument rupture and the beginning of primary root protrusion, the seeds were placed under a $12 \mathrm{~h}$ photoperiod (day and night), maintaing the temperature alternation.

\section{INDUCTION OF SOMATIC EMBRYOGENESIS}

In laminar flow hood, cotyledonary leaves (CL), excised from 30-day-old in vitro seedlings, were inoculated into sterile glass Petri dishes (100x20 $\mathrm{mm}$ ) containing 25-30 mL of somatic embryogenesis induction medium: MS, MI (0.55 mM), sucrose $(87.5 \mathrm{mM})$, Vetec ${ }^{\circledR}$ agar $\left(8 \mathrm{~g} \mathrm{~L}^{-1}\right)$ and supplemented with 4-CPA [4-chlorophenoxyacetic acid] $(25 \mu \mathrm{M})$. After explant inoculation, the Petri dishes were sealed with PVC plastic film (Goodyear ${ }^{\circledR}$, Brazil), wrapped with aluminum foil to prevent light, and incubated at $27 \pm 1{ }^{\circ} \mathrm{C}$ for 50 days.

\section{SOMATIC EMBRYO MATURATION}

\section{Experiment 1 - Polyethylene glycol (PEG) on}

'Golden THB' papaya somatic embryo maturation

After 50 days on the induction medium with 4-CPA $(25 \mu \mathrm{M})$, the embryogenic calli were transferred to the maturation media (MM1) consisting of MS, MI $(0.55 \mathrm{mM})$, sucrose $(87.5 \mathrm{mM})$, Vetec ${ }^{\circledR}$ agar $\left(8 \mathrm{~g} \mathrm{~L}^{-1}\right)$ and supplemented with abscisic acid ABA $(0.5 \mu \mathrm{M})$, active charcoal - AC $\left(15 \mathrm{~g} \mathrm{~L}^{-1}\right)$ and polyethylene glycol - PEG 6000 concentrations ( 0 ; 40; 50; 60 and $\left.70 \mathrm{~g} \mathrm{~L}^{-1}\right)$. All media were autoclaved for 20 minutes at $121{ }^{\circ} \mathrm{C}$ and at $1.05 \mathrm{~kg} \mathrm{~cm}^{-2}$ pressure, dispensed into $100 \times 20 \mathrm{~mm}$ sterile glass Petri dishes, sealed with PVC plastic film, and incubated in BOD at $27 \pm 1{ }^{\circ} \mathrm{C}$ and photoperiod of 
$12 \mathrm{~h}$, providing irradiance of $25 \mu \mathrm{mol} \mathrm{m} \mathrm{m}^{-2} \mathrm{~s}^{-1}$, for 45 days.

Using a Motic ${ }^{\circledR}$ SMZ 168 stereomicroscope, 10x magnification and $1.5 \mathrm{x}$ objective lens power, the total number of somatic embryos; number of normal cotyledonary embryos; number of abnormal cotyledonary embryos; and number of germinated cotyledonary embryos were recorded.

\section{Experiment 2 - Malt extract on 'Golden THB' papaya somatic embryo maturation}

After 50 days on the induction medium with 4-CPA $(25 \mu \mathrm{M})$, the embryogenic calli were transferred to the maturation media (MM2) consisting of MS, MI (0.55 mM), sucrose $(87.5 \mathrm{mM})$, Vetec ${ }^{\circledR}$ agar $\left(8 \mathrm{~g} \mathrm{~L}^{-1}\right), \mathrm{ABA}(0.5 \mu \mathrm{M}), \mathrm{AC}\left(15 \mathrm{~g} \mathrm{~L}^{-1}\right)$ and $\mathrm{ME}$ concentrations $\left(0 ; 0.1 ; 0.2 ; 0.3\right.$ and $\left.0.4 \mathrm{~g} \mathrm{~L}^{-1}\right)$.

Using a Motic ${ }^{\circledR}$ SMZ 168 stereomicroscope, 10x magnification and $1.5 \mathrm{x}$ objective lens power, the total number of somatic embryos; number of globular, heart-shaped, torpedo-shaped and cotyledonary embryos; number of normal cotyledonary embryos; number of abnormal cotyledonary embryos; and number of germinated cotyledonary embryos were recorded.

\section{GERMINATION OF SOMATIC EMBRYOS}

\section{Experiment 3 - Myo-inositol on 'Golden THB'} papaya somatic embryo germination

Normal cotyledonary embryos generated on MM2 supplemented with ABA $(0.5 \mu \mathrm{M}), \mathrm{AC}\left(15 \mathrm{~g} \mathrm{~L}^{-1}\right)$, and $\operatorname{ME}\left(0.2 \mathrm{~g} \mathrm{~L}^{-1}\right)$ were transferred to germination medium (MG), Sucrose $(87.5 \mathrm{mM})$, $\operatorname{Vetec}^{\circledR}$ agar $(8$ $\left.\mathrm{g} \mathrm{L}^{-1}\right)$, and $\mathrm{MI}$ concentrations $(0 ; 0.275 ; 0.55 ; 0.825$ $\mathrm{mM})$ for 30 days. The percentage of germination and root mean number were calculated.

\section{PREPARATION OF MICROSCOPY SAMPLES}

Samples composed of fragments of embryogenic calli and somatic embryos were collected from the medium supplemented with $\operatorname{ME}\left(0.2 \mathrm{~g} \mathrm{~L}^{-1}\right)$ and fixed in Karnovsky solution [glutaraldehyde (2.5\%) and paraformaldehyde (4.0\%) in $0.1 \mathrm{M}$ monobasic potassium phosphate buffer $(\mathrm{pH} 7.2)$ and $5 \mathrm{mM}$ calcium chloride] (Karnovsky 1965).

\section{SCANNING ELECTRON MICROSCOPY}

The fixed samples were dehydrated in ethanol series to absolute alcohol and dried at a critical point with $\mathrm{CO}_{2}$ (Autosamdri 815, Tousimis ${ }^{\circledR}$ ), mounted on stubs and sputter coated with gold (Desk V, Denton Vacuum ${ }^{\circledR}$ ). Analyses and photo documentation were performed using a scanning electron microscope (JSM-6610LV, Jeol ${ }^{\circledR}$ ) and the images were digitally processed. The analyses were carried out at the Laboratório de Ultraestrutura Celular Carlos Alberto Redins, Universidade Federal do Espírito Santo.

\section{STATISTICAL ANALYSIS}

The maturation phase experiments were carried out with calli derived from cotyledon leaf explants using 4-CPA $(25 \mu \mathrm{M})$. The treatments were arranged in a completely randomized experimental design (CRD), with four replicates formed by three Petri dishes, each containing four explants, totaling 48 explants per treatment.

The germination phase experiment was arranged in CRD consisting of four treatments with five replicates formed by four Petri dishes containing five somatic embryos, totaling 100 somatic embryos for each treatment.

Data were examined by analysis of variance and the means of the different concentrations of maturation and germination inducers were submitted to regression analysis, using the Genes Program (Cruz 2016). Root-mean-square errors (RMSE) were obtained by the equation:

$$
=\sqrt{\frac{\sum_{i=1}^{N}(\mathrm{Pi}-\mathrm{Hi})^{2}}{N}}
$$


Where: Pi are the estimated values; Hi are the measured values; $\mathrm{N}$ is the number of observations.

The root-mean-square error (RMSE) informs the actual value of the error produced by the model (Souza et al. 2011). It usually expresses the accuracy of numerical results with the advantage that RMSE has errors in the same dimensions of the analyzed variable (Hallak and Pereira Filho 2011). The lower this measure, the better the model performance in making estimates (Souza and Escobedo 2013).

\section{RESULTS}

\section{MATURATION}

\section{Experiment 1 - Polyethylene glycol (PEG) on} 'Golden THB' papaya somatic embryo maturation

In the maturation of 'Golden THB' papaya somatic embryos in different PEG 6000 concentrations, the total number of somatic embryos, number of normal cotyledonary embryos, and number of germinated cotyledonary embryos showed significant difference by the $\mathrm{F}$ test at $1 \%$ probability level. However, the number of abnormal cotyledonary somatic embryos showed no significant difference at $5 \%$ probability level, with mean of 6.54 (Table I).

These variables were analysed by means of regression analysis, showing that only the number of germinated cotyledonary embryos had quadratic trend (Figure 1c), while the others had linear and decreasing trend with increasing PEG
6000 concentrations (Figure $1 \mathrm{a}$ and $\mathrm{b}$ ) and the largest root-mean-square error (RMSE) (1.2373) was found for the total number of embryos (Figure 1a). The absence of PEG 6000 in the maturation phase produced the highest estimated total number of somatic embryos per callus (17.58). With increasing PEG concentrations, there was reduction in the number of total somatic embryos up to $70 \mathrm{~g}$ $\mathrm{L}^{-1}$ PEG, with 12 embryos per callus, a difference of $31.85 \%$ in relation to the control (Figure 1a).

The number of normal cotyledonary somatic embryos showed a decreasing linear trend, in which the control had the highest mean estimated at 9.02. With increasing PEG 6000 concentrations, there was reduction in the normal somatic embryos by approximately $54 \%$ when comparing the absence of PEG with the maximum concentration of $70 \mathrm{~g}$ $\mathrm{L}^{-1}$ (Figure 1b).

For the number of germinated somatic embryos, the effect was quadratic, with the maximum number of germinated somatic embryos (1.66) recorded at $70 \mathrm{~g} \mathrm{~L}^{-1}$ of PEG 6000, and in its absence, the number of germinated embryos was 1.59 (Figure 1c).

\section{Experiment 2 - Malt extract on 'Golden THB' papaya somatic embryo maturation}

The maturation of 'Golden THB' papaya somatic embryos in different concentrations of ME showed significant difference at $1 \%$ probability level for all variables analyzed (Table II).

TABLE I

Analysis of variance for total number of somatic embryos (TNSE), number of normal cotyledonary embryos (NNCE), number of abnormal cotyledonary embryos (NACE) and number of germinated cotyledonary embryos (NGCE) of $C$. papaya $\mathrm{L}$. 'Golden THB' after $\mathbf{4 5}$ days of culture on maturation medium.

\begin{tabular}{cccccc}
\hline Variables & $\begin{array}{c}\text { Variations } \\
\text { between }\end{array}$ & Variations within & F $_{\text {Calculated }}$ & Averages & CV (\%) \\
\hline TNSE & 26.57 & 1.93 & $13.71^{* *}$ & 14.03 & 9.91 \\
NNCE & 17.35 & 1.04 & $16.67^{* *}$ & 5.91 & 17.23 \\
NACE & 2.56 & 0.99 & $2.58^{\text {ns }}$ & 6.54 & 15.22 \\
NGCE & 1.42 & 0.08 & $15.87^{* *}$ & 1.26 & 23.74 \\
\hline
\end{tabular}

${ }^{* *}$ Significant at $\mathrm{p} \leq 0.01$ probability by $\mathrm{F}$ test; ${ }^{\mathrm{ns}}$ Non-significant; $\mathrm{CV}=$ Coefficient of Variation. 

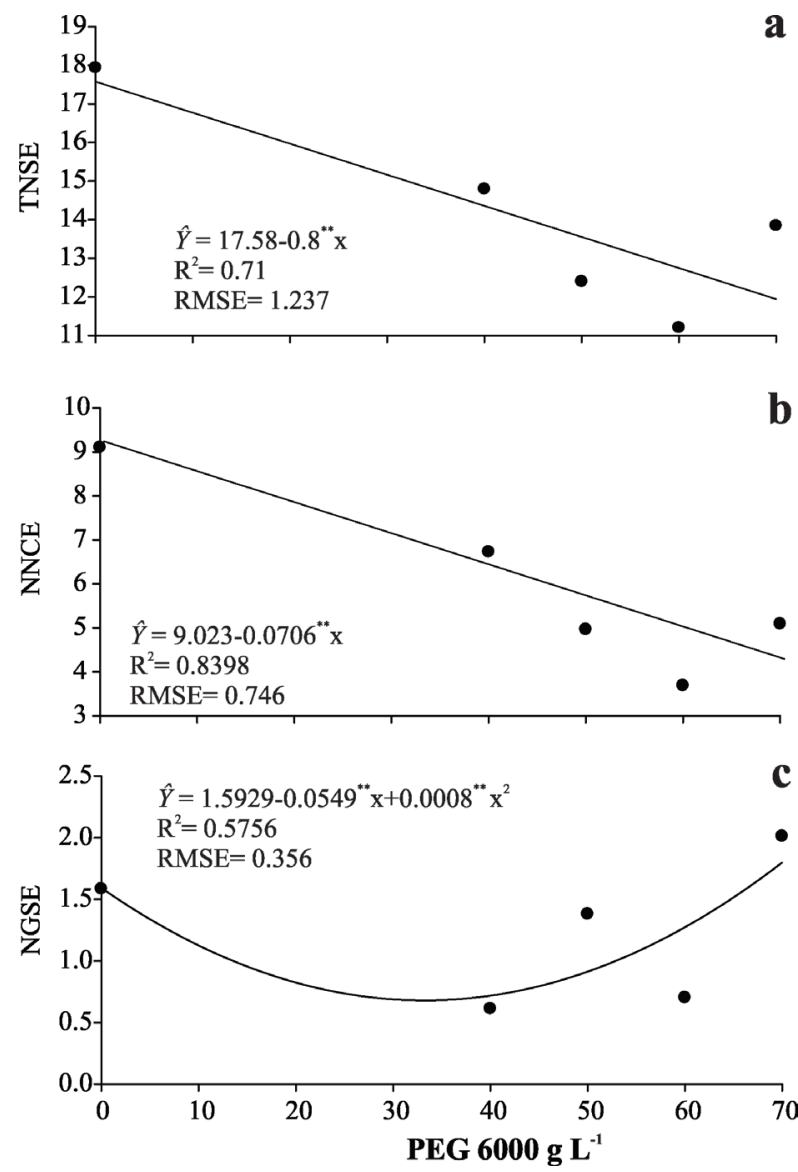

Figure 1 - Total number of somatic embryos (a), number of normal cotyledonary embryos (b) and number of germinated somatic embryos (c) per callus of $C$. papaya L. 'Golden THB', on maturation medium with different concentrations of polyethylene glycol $6000\left(0 ; 40 ; 50 ; 60\right.$ and $\left.70 \mathrm{~g} \mathrm{~L}^{-1}\right)$ after 45 days of culture. ${ }^{* *}$ Significant at $\mathrm{p} \leq 0.01$ probability level by the F test.

After a 45-day maturation period, the concentration of malt extract estimated at 0.17 $\mathrm{g} \mathrm{L}^{-1}$ resulted in the highest total number of somatic embryos per callus (45.4) (Figure 2a). The concentrations of $0.1 ; 0.2 ; 0.3$ and $0.4 \mathrm{~g} \mathrm{~L}^{-1}$ showed means and differences regarding the number of somatic embryos per callus compared to the concentration of $0.17 \mathrm{~g} \mathrm{~L}^{-1}$ of 41.88 (3.52); 44.72 (0.68); 33.22 (12.18), and 7.38 (38.02), respectively (Figure 2a).

The lack of synchronism in the development of somatic embryos and the occurrence of secondary somatic embryogenesis on maturation medium supplemented with ME (Figure 3r), resulted in the emergence of embryos in different stages of histodifferentiation (globular, heart-shaped, torpedo-shaped, and cotyledonary). The regression analysis showed a quadratic trend for the number of globular (Figure 2b), heart-shaped (Figure 2c), torpedo-shaped (Figure 2d), and cotyledonary (Figure 2e) somatic embryos. The concentration $0.18 \mathrm{~g} \mathrm{~L}^{-1}$ of malt extract resulted in the highest estimated number of globular somatic embryos (6.05 callus $\left.{ }^{-1}\right)$ (Figure 2b); $0.19 \mathrm{~g} \mathrm{~L}^{-1}$ of heartshaped (4.58 callus $^{-1}$ ) (Figure 2c); $0.18 \mathrm{~g} \mathrm{~L}^{-1}$ of torpedo-shaped $\left(6.55\right.$ callus $\left.^{-1}\right)$ (Figure $2 \mathrm{~d}$ ); and $0.16 \mathrm{~g} \mathrm{~L}^{-1}$ of cotyledonary $\left(27.57\right.$ callus $\left.^{-1}\right)$ somatic embryos (Figure 2e). The highest root mean square error (6.673) was recorded for the total number of somatic embryos (Figure 2a), while the lowest RMSE (0.130) was recorded for the number of germinated cotyledonary embryos (Figure $2 \mathrm{~h}$ ).

The equation fitted for normal cotyledonary somatic embryos showed the point of maximum efficiency for $\mathrm{ME}$ at the concentration of $0.15 \mathrm{~g} \mathrm{~L}^{-1}$ (18.23 callus $^{-1}$ ) (Figure 2h), in which the responses tend to decrease from this concentration. This normal condition is evidenced when comparing the normal somatic embryo (Figure $3 h$ ) with the normal zygotic embryo (Figure 3i). The presence of abnormalities was higher at the concentration $0.19 \mathrm{~g}$ $\mathrm{L}^{-1}$ of ME (9.42 callus ${ }^{-1}$ ) (Figure $2 \mathrm{~g}$ ). There is a fine adjustment between the best and worst concentration of ME to produce normal and abnormal embryos. The development of apparently globular structures formed by clustered embryos (Figure 3s) contributed to the enlargement of this variable in the respective concentration. Morphological abnormalities were observed in somatic embryos, such as embryos with fused cotyledons (Figure 3n, o), polycotyledonary embryos (Figure 3q), and fused embryos (Figure 3p).

There was a larger number of germinated embryos in the absence of ME (1.76 GSE callus $^{-1}$ ) (Figure 2h). The decreasing linear trend demonstrates the efficiency of malt extract addition 
TABLE II

Analysis of variance for total number of somatic embryos (TNSE), number of globular embryos (NGLSE), number of heartshaped embryos (NHSE), number of torpedo-shaped somatic embryos (NTSE), number of cotyledonary embryos (NCSE), number of normal cotyledonary embryos (NNCSE), number of abnormal cotyledonary embryos (NASE), and number of germinated cotyledonary embryos (NGSE) of $C$. papaya L. 'Golden THB' after 45 days of culture on maturation medium.

\begin{tabular}{cccccc}
\hline Variables & $\begin{array}{c}\text { Variations } \\
\text { between }\end{array}$ & Variations within & F $_{\text {Calculated }}$ & Averages & CV (\%) \\
\hline TNSE & 1129.85 & 6.90 & $192.39^{* *}$ & 30.38 & 8.64 \\
NGLSE & 32.77 & 1.10 & $29.84^{* *}$ & 3.44 & 30.45 \\
NHSE & 8.97 & 0.08 & $110.35^{* *}$ & 3.09 & 9.22 \\
NTSE & 17.73 & 0.26 & $67.51^{* *}$ & 4.57 & 11.19 \\
NCSE & 443.45 & 3.26 & $136.19^{* *}$ & 18.35 & 9.83 \\
NNCSE & 256.85 & 1.09 & $235.68^{* *}$ & 12.03 & 8.68 \\
NASE & 35.65 & 1.23 & $29.04^{* *}$ & 6.31 & 17.56 \\
NGSE & 1.88 & 0.008 & $243.69^{* *}$ & 0.91 & 9.62 \\
\hline
\end{tabular}

${ }^{* *}$ Significant at $\mathrm{p} \leq 0.01$ probability by test $\mathrm{F} ; \mathrm{CV}=$ Coefficient of Variation.
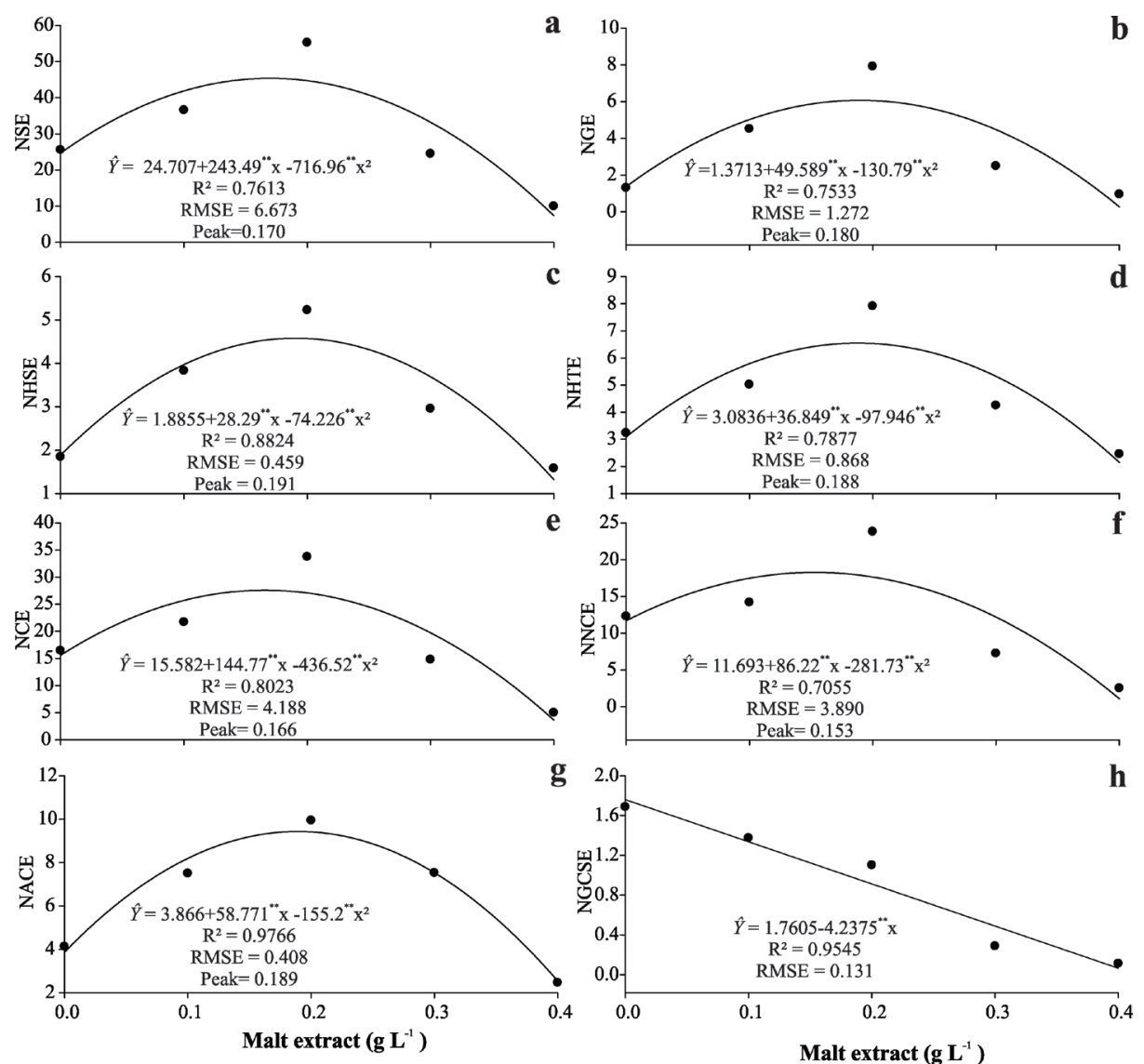

Figure 2 - Number of somatic embryos (a), number of globular embryos (b), number of heartshaped embryos (c), number of torpedo-shaped embryos (d) number of cotyledonary embryos (e), number of normal cotyledonary embryos (f), Number of abnormal cotyledonary embryos (g), and number of germinated cotyledonary somatic embryos (h) per callus of C. papaya L. 'Golden THB' on maturation medium with different concentrations of malt extract $0.1 ; 0.2 ; 0.3 ; 0.4 \mathrm{~g} \mathrm{~L}^{-1}$ after 45 days of culture. ${ }^{* *}$ Significant at $\mathrm{p} \leq 0.01$ probability level by the $\mathrm{F}$ test. 


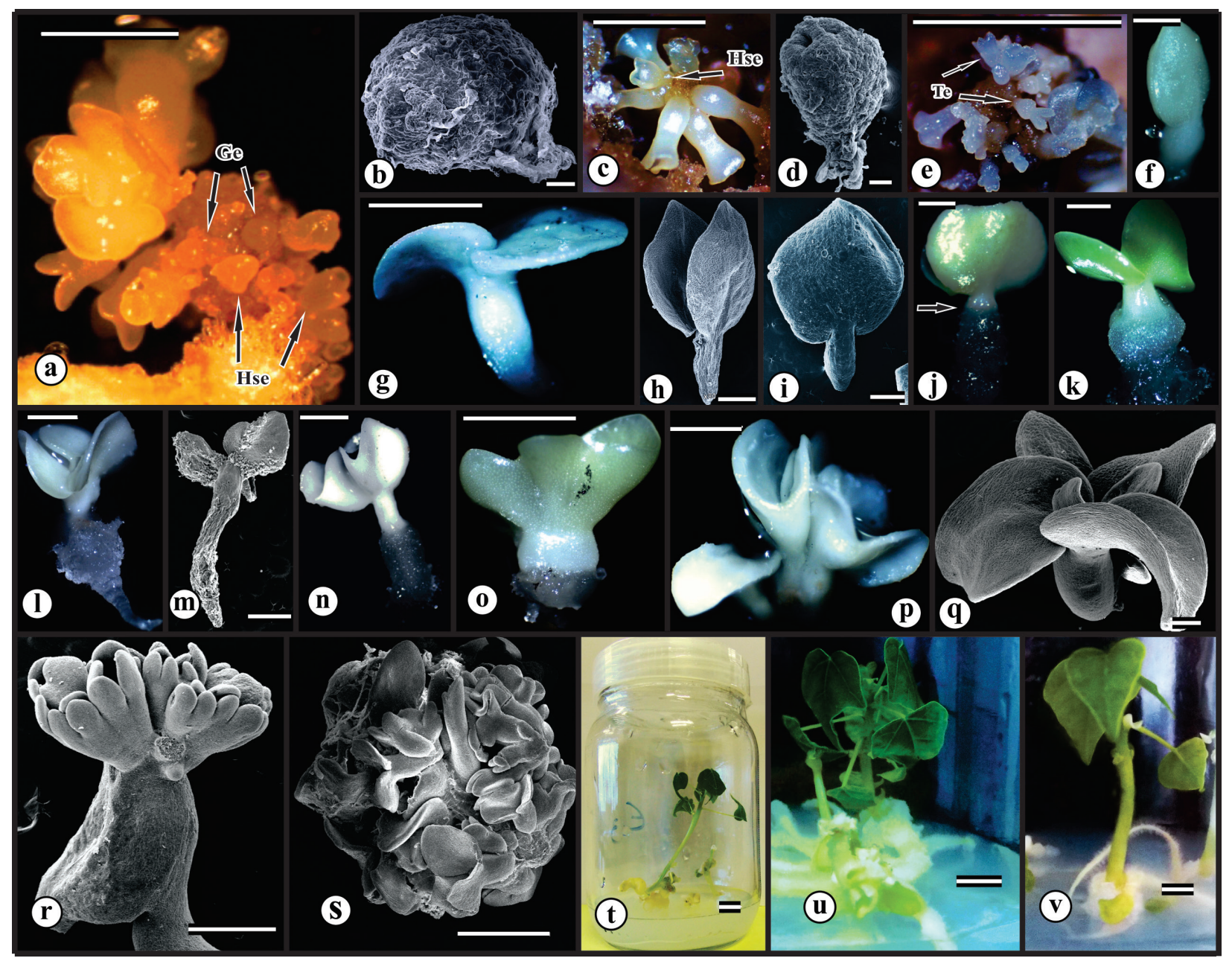

Figure 3 - Maturation of somatic embryos of C. papaya L. 'Golden THB' somatic embryos at different stages of development: (a) Embryogenic callus with somatic embryos; (b) Globular embryo; (c, d) Heart-shaped somatic embryos; (e, f) Torpedo-shaped somatic embryos; (g, h) Morphologically normal cotyledonary embryos; (i) Zygotic embryo. Germinated somatic embryos: (j) Normal embryo (arrow) detail of the transition region between root and shoot; (k, l) Normal germinated embryo with chlorophyllated cotyledon leaves; (m) Normal germinated embryo. Abnormal embryos: (n) Germinated abnormal embryo; (o) Embryo with fused cotyledons; (p) Fused somatic embryos; (q) Polycotyledonay embryo; (r) Secondary embryogenesis; (s) Globular mass of somatic embryos. Normal seedlings developed from somatic embryos: (t) 30 days after germination; (u, v) 65 days after germination. Abbreviations: $\mathrm{Ge}=$ globular embryo; Hse = heart-shaped embryo; Te = torpedo-shaped embryo. Bar: $100 \mu \mathrm{m}(\mathbf{b}, \mathbf{d}) ; 200 \mu \mathrm{m}(\mathbf{h}$, q); $500 \mu \mathrm{m}(\mathbf{i}, \mathbf{m}, \mathbf{r}) ; 0.5 \mathrm{~mm}(\mathbf{f}) ; 1.0 \mathrm{~mm}(\mathbf{a}, \mathbf{c}, \mathbf{e}, \mathbf{g}, \mathbf{j}, \mathbf{k}, \mathbf{l}, \mathbf{n}, \mathbf{o}, \mathbf{p}, \mathbf{s}) ; 0.5 \mathrm{~cm}(\mathbf{u}, \mathbf{v}) ; 1.0 \mathrm{~cm}(\mathbf{t})$.

to the maturation medium, which is used to delay germination.

\section{GERMINATION}

\section{Experiment 3 - Myo-inositol on 'Golden THB'}

papaya somatic embryo germination

After the maturation phase, the somatic embryos were transferred to germination medium with different MI concentrations to evaluate primary root protrusion and conversion to normal seedlings. The analysis of variance detected a significant difference at $1 \%$ probability by the $\mathrm{F}$ test for percentage of germinated embryos (Table III).

The concentration of myo-inositol estimated at $0.45 \mathrm{mM}$ provided the highest germination percentage (47.42\%) (Figure 4). However, there was no significant difference for number of roots 
TABLE III

Analysis of variance of percentage of germination (G) and root mean number (RMN) for somatic embryos of $C$. papaya L. 'Golden THB', on germination medium with different concentrations of myo-inositol.

\begin{tabular}{cccccc}
\hline Variables & $\begin{array}{c}\text { Variations } \\
\text { between }\end{array}$ & Variations within & F $_{\text {Calculated }}$ & Averages & CV (\%) \\
\hline G (\%) & 111.58 & 18.410 & $6.058^{* * *}$ & 42.125 & 10.18 \\
RMN & 0.112 & 0.068 & $1.65^{\mathrm{ns}}$ & 1.51 & 17.28 \\
\hline
\end{tabular}

${ }^{\mathrm{ns}}$ Non-significant; ${ }^{* *}$ Significant at $\mathrm{p} \leq 0.01$ probability by the $\mathrm{F}$ test.

per embryo, with a mean of 1.51 roots/embryo (Table III), which enabled the development of normal seedlings after 30 (Figure 3t) and 65 days of cultivation (Figure $3 \mathrm{u}, \mathrm{v}$ ). According to that observed in Figure $3 u$ and v, root development was impaired by the formation of calli at the base of the seedling, preventing the emission and growth of the roots.

\section{DISCUSSION}

\section{MATURATION}

Experiment 1 - Polyethylene glycol (PEG) on

'Golden THB' papaya somatic embryo maturation

In this study, the control treatment supplemented with $(0.5 \mu \mathrm{M}) \mathrm{ABA}+\left(15 \mathrm{~g} \mathrm{~L}^{-1}\right) \mathrm{AC}$ and no addition of PEG 6000 developed the most total somatic embryos and normal somatic embryos (9) (Figure 1a,b). The opposite was found in the treatments with PEG, which were unfavorable to embryo formation, resulting in 4.7 and 4 normal cotyledonary somatic embryos at the concentrations of 60 and $70 \mathrm{~g} \mathrm{~L}^{-1}$, respectively (Figure 2b). Regarding maturation, somatic embryos of 'Golden THB' did not respond well to PEG 6000-mediated stress. Larger PEG molecules are not permeable to the cell wall, therefore, they undergo plasmolysis without this osmotic agent entering the cell. In this way, the turgor pressure and the intracellular osmotic potential are reduced (von Arnold et al. 2002). However, during the maturation of papaya 'Pusa Delicious' papaya somatic embryos, the highest conversion of somatic embryos from the globular to the cotyledonary stage (28\%) was obtained with 4.2\% PEG, producing normal seedlings (Mishra et al. 2010). Rancé et al. (1994) discussed that embryo desiccation treatments such as those produced by PEG can cause rapid biochemical changes, triggering the activity of specific proteins. Evidence for these effects was demonstrated by Vale et al. (2014) studying the response of papaya hybrid UENF/Caliman 01 to PEG6000 $\left(60 \mathrm{~g} \mathrm{~L}^{-1}\right)$, which resulted in the expression of three proteins (enolase, esterase and ADH3) important during maturation and characterized as biomarkers, producing 40 cotyledonary somatic embryos in 300 mg of callus (Vale et al. 2014). The authors found that enolase was the most abundant protein and it is associated with metabolism and energy supply.

In the somatic embryogenesis of immature zygotic embryos of papaya hybrid UENF/Caliman 01 , the treatment containing $60 \mathrm{~g} \mathrm{~L}^{-1}$ PEG 3350 resulted in the highest maturation responses $(83.3 \%)$, with the most somatic embryos formed per callus (78) (Heringer et al. 2013). The authors reported that cultures maintained on PEG 3350 $\left(60 \mathrm{~g} \mathrm{~L}^{-1}\right)$ showed the highest concentration of soluble proteins ( $9.4 \mathrm{mg} \mathrm{g}^{-1}$ fresh weight) in the treatment of PEG $3350\left(60 \mathrm{~g} \mathrm{~L}^{-1}\right)$. This increase in protein may be related to LEA (Late Abundant Embryogenesis) synthesis, whose expression is associated with acquisition of embryo desiccation tolerance and in response to stress caused by cold or osmotic pressure. Koehler et al. (2013) reported that the addition of $50 \mathrm{~g} \mathrm{~L}^{-1}$ PEG 2000 together with $2 \mathrm{~g} \mathrm{~L}^{-1}$ activated charcoal and $5 \mu \mathrm{M}$ ABA improved somatic embryo quality and plantlet 
formation of papaya 'Golden'. These authors used PEG 3350 (Heringer et al. 2013) and PEG 2000 (Koehler et al. 2013), whereas this present study tested concentrations of PEG 6000, with higher molecular weight, which may partly explain the differences found.

In Picea glauca (Stasolla et al. 2003, Belmonte et al. 2005) and Aesculus hippocastanum (Troch et al. 2009), PEG 8000 was essential for the conversion of somatic embryos to seedlings. However, Márquez-Martín et al. (2011) reported that with PEG 8000, the somatic embryo production of Persea americana Mill. was significantly lower than the control, showing that the PEG effect depends on the concentration and molecular weight used for a particular genetic material.

The early germination of somatic embryos during maturation follows an irregular pattern with supplementation of PEG 6000 (Figure 1c), which was also reported by Rai et al. (2009) in the maturation of Psidium guajava L. somatic embryos on medium supplemented with PEG 6000. According to these authors, PEG 6000 concentrations of $0 ; 5 ; 10 ; 20$ and $40 \mathrm{~g} \mathrm{~L}^{-1}$ provided mean seedling conversions of $68.6 ; 42 ; 52.9 ; 59.6$; and $38.5 \%$ germination, respectively.

\section{Experiment 2 - Malt extract on 'Golden THB' papaya somatic embryo maturation}

Maturation is a critical step in the development of somatic embryos. This phase is characterized by the expansion, differentiation and accumulation of the embryonic reserve, and hence determinant in germination and conversion to normal seedlings (Mishra et al. 2012).

The addition of $\operatorname{ME}\left(0.17 \mathrm{~g} \mathrm{~L}^{-1}\right)$ in the maturation medium [ABA $(0.5 \mu \mathrm{M})+$ active charcoal $\left.\left(15 \mathrm{~g} \mathrm{~L}^{-1}\right)\right]$ resulted in the most total somatic embryos per callus $(45 ; 40)$ (Figure 2a) of papaya 'Golden THB', which was higher than the rate of somatic embryogenesis ( $35 \mathrm{SE}$ callus $^{-1}$ ) found for 'Golden' papaya (Clarindo et al. 2008). Carimi et al. (1998) reported high frequency (74\%) of conversion of Citrus sinensis L. Osb. somatic embryos to plantlets after transfer to MS medium supplemented with sucrose (146 mM) and ME (500 $\mathrm{mg} \mathrm{L}^{-1}$ ). Jumin and Nito (1996) showed that ME in the culture medium results in a greater number of mitotic divisions, which increases the plating efficiencies of Citropsis schweinfurthii protoplasts. Vardi and Galun (1988) argued that to accelerate the development of globular somatic embryos of citrus and to obtain embryos with normal morphology and expanded cotyledonary leaves, they should be transferred to medium containing $0.5 \mathrm{~g} \mathrm{~L}^{-1} \mathrm{ME}$.

ME stimulates hydrolytic enzymes activity (Kim et al. 2010), since it is an important source of $\alpha$-amylase, $\beta$-amylase, and $\alpha$-glycosidase (Evans et al. 2009), which facilitate the breakdown of starch to reducing sugars such as glucose and maltose (Jung et al. 2011). However, in the present work, at ME concentrations higher than $0.17 \mathrm{~g} \mathrm{~L}^{-1}$, high availability of glucose to the plant cells may occur, hindering photoautotrophic functioning and allowing heterotrophic growth, with subsequent harmful photooxidative effects (Ashton and Ziegler 1987). Couée et al. (2006) found that the accumulation of soluble sugars is associated with the production of reactive oxygen species (ROS). According to these authors, the accumulation of sugars negatively regulates the gene expression of photosynthesis, including the expression of the Calvin cycle, which can reduce NADP recycling and cause excessive transfer of electrons, leading to ROS production.

However, sugars, as carbon and energy sources, not only enhance plant growth and development, but also exert important regulatory functions as signaling molecules of different molecular mechanisms. These mechanisms control transcription, translation, protein stability and the enzymatic activity of hexokinase (HXKdependent and HXK-independent), which exhibits 
hexose-phosphorylation catalytic activity (BolouriMoghaddam et al. 2010).

The rise of embryos in different stages of differentiation (globular, heart-shaped, torpedoshaped and cotyledonary) (Figure 3a) is partly related to the stimulus to secondary embryogenesis, due to the composition of the maturation medium such as its supplementation with malt extract, which at the concentration of $0.2 \mathrm{~g} \mathrm{~L}^{-1}$ provided the greatest formation of secondary embryos. Induction of secondary embryogenesis can be explained by the presence of relatively large amount of indolil3-acetic acid (IAA) in ME (Dix and Van Staden 1982).

Oliveira et al. (1994) cultured nucellar embryogenic calli of 'Rangpur lime' (Citrus limonia Osbeck) on MT medium (Murashige and Tucker 1969) supplemented with $0.5 \mathrm{~g} \mathrm{~L}^{-1} \mathrm{ME}$ and no growth regulators; they found $38.8 \%$ embryo induction, with more friable calli and a lower oxidation level, surpassing other media with BAP $(44.4 \mu \mathrm{M})$ and the combination of IAA $(5.7 \mu \mathrm{M})$ with $\mathrm{KIN}(0.5 \mathrm{M})$.

In the present work, somatic embryos developed on maturation medium lacking ME; however, the culture medium supplemented with $\operatorname{ME}\left(0.15 \mathrm{~g} \mathrm{~L}^{-1}\right)$ provided higher number of normal somatic embryos. These results suggest that $\mathrm{ME}$ is not determinant for formation of papaya somatic embryos, but its use increases the production of normal somatic embryos, with a clear distinction between the embryonic axis and the cotyledons (Figure 3g, h and j). Nonetheless, the formation of abnormal embryos of 'Golden THB' papaya was also observed when they were cultured on medium with ME (Figure 2g), corroborating with the work of Anandan et al. (2012) with papaya 'Golden', Cipriano et al. (2018) with 'Golden THB', Vale et al. (2014) with 'Golden' and F2 generation of the hybrid Uenf/Caliman 01, and other species such as Glycine max (Korbes and Droste 2005, Santos et al. 2006, Hiraga et al. 2007), Cassia angustifolia
(Agrawal and Sardar 2007), Gossypium hirsutum (Hussain et al. 2009) and Desmodium motorium (Devi and Narmathabai 2011).

The presence of globular structures in the callus (Figure 3s), resulting from the disordered development of clustered somatic embryos of 'Golden THB' papaya, creates competition for space. In this present study, the rise of these structures may be linked to the agar-solidified culture medium, on which embryos develop statically, unlike liquid media under agitation, where embryos detach from the callus and grow individually without competing for space. Castillo et al. (1998) compared the maturation and subsequent conversion to plants of C. papaya L. 'Solo' and found that embryogenic calli cultured in a liquid phase maturation medium resulted in a significantly higher frequency of somatic embryogenesis (SE) and regeneration than treatments on agar-solidified medium. Anandan et al. (2010) reported that suspension cultures (liquid medium) of papaya ' $\mathrm{Co} 7$ ' were superior to static cultures (semi-solid medium) for the maturation of somatic embryos.

For 'Golden THB' papaya, the addition of $15 \mathrm{~g} \mathrm{~L}^{-1} \mathrm{AC}$ appears to be optimal or close to optimal since, in combination with $0.5 \mu \mathrm{M} \mathrm{ABA}$, it probably acts absorbing inhibitory substances and allows the continuous and adequate release of this hormone into the embryogenic tissue, favoring its development (Cipriano et al. 2018). The authors point out that another positive effect of $0.5 \mu \mathrm{M}$ $\mathrm{ABA}+15 \mathrm{~g} \mathrm{~L}^{-1} \mathrm{CA}$ is the low germination of embryos in maturation phase, approximately $4 \%$ (2.82 SE callus $\left.{ }^{-1}\right)$. However, in the present work, the mean of 1.7 germinated SE callus ${ }^{-1}$ (Figure 2h) was recorded for the same $\mathrm{ABA}$ and $\mathrm{AC}$ concentrations and, with addition of $0.4 \mathrm{~g} \mathrm{~L}^{-1}$ malt extract to maturation medium, there was greater reduction in the germination of somatic embryos $\left(0.06\right.$ GSE callus $\left.^{-1}\right)$. This is a promising way to delay the development of somatic embryos in order to maintain in vitro germplasm banks. 


\section{GERMINATION}

Experiment 3 - Myo-inositol on 'Golden THB' papaya somatic embryo germination

Among the different MI concentrations in the germination medium, $0.45 \mathrm{mM}$ resulted in significant gains in the germination percentage of 'Golden THB' papaya somatic embryos (47.42\%), an increase of $11.19 \%$, while the medium lacking MI provided $36.23 \%$ germination (Figure 4).

MI is a cyclic polyalcohol, an important cellular constituent involved in different biochemical processes (Almeida et al. 2003). In plants, MI is a precursor of several metabolites, leading to the production of phytic acid via the sequential phosphorylation of myo-inositol by myo-inositol3-phosphate synthase (MIPS) (Abreu and Aragão 2007). Phytic acid is the major storage form of phosphorous in plant seeds used during seedling germination and growth (Shi et al. 2005). The gibberellin signaling pathway (GA) has biological relationships with inositol phosphates (Zhang et al. 2016). Myo-inositol hexachyphosphate (phytic acid, IP6) is hydrolyzed by phytase in the presence of GA, releasing inorganic phosphorus and inositol phosphates during seed germination (Greiner et al. 2007).

MI is also related to the synthesis of other compounds, for example, forming galactinol by transferring galactosyl to an MI molecule. Galactinol, in turn, donates the galactose moiety to a sucrose molecule forming raffinose with the release of an MI molecule, and this is related to increased resistance to stress (Wang et al. 2012, Zhuo et al. 2013, Redekar et al. 2015). In Poaceae species (Deschampsia antartica Desv. and Poa annua L.) the highest content of cyclitols (MI, D-pinitol and D-ononitol) occurs when cell division ends, with gradual decreases during seed development and maturation (Kellmann-Sopyla et al. 2015).

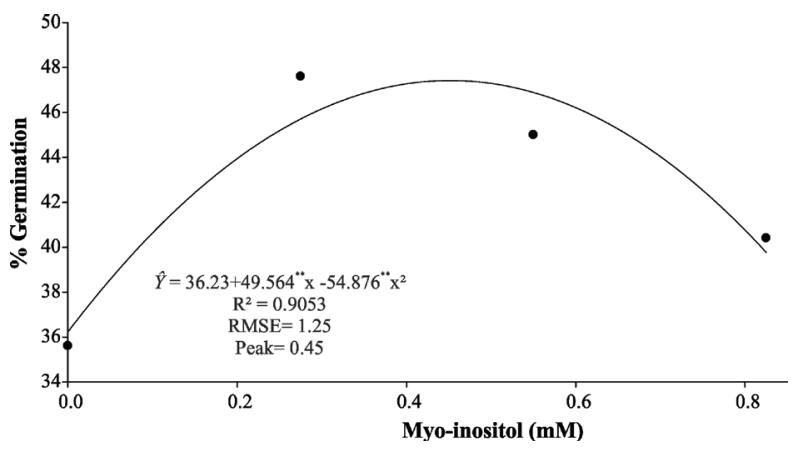

Figure 4 - Germination (\%) of somatic embryos of C. papaya L. 'Golden THB' on germination medium with different concentrations of myo-inositol $(0 ; 0275 ; 0.55 ; 0.825 \mathrm{mM})$ after 30 days of culture. ${ }^{*}$ Significant at $\mathrm{p} \leq 0.01$ probability level by the $\mathrm{F}$ test.

The low number of roots per embryo (1.51) (Table III), obtained in this work, corroborates Posada-Pérez et al. (2017), where the emission of secondary roots is hampered by callus formation at the main root axis. These authors achieved the complete germination of papaya 'Maradol Roja' somatic embryos with low callus formation (13\%) using phloroglucinol at a concentration of $475.8 \mu \mathrm{M}$ in semi-solid medium. Posada-Pérez et al. (2016) verified that phloroglucinol stimulates the elongation and the formation of new roots of 'Maradol Roja' papaya in relation to the control. However, the best results for in vitro shoots rooting were obtained with $79 \mu \mathrm{M}$ phloroglucinol and $9.8 \mu \mathrm{M}$ indolil-3-butyric acid (100\%), resulting in a root mean length of 2.40 $\mathrm{cm}$ and 1.76 roots per shoot.

\section{CONCLUSIONS}

Maturation of 'Golden THB' papaya somatic embryos on medium containing PEG 6000 at the concentrations studied is not recommended.

The supplementation of maturation medium with $0.153 \mathrm{~g} \mathrm{~L}^{-1}$ malt extract promoted the greatest development of normal cotyledonary somatic embryos (18.28).

Germination of 'Golden THB' papaya somatic embryos is best on MS medium containing 0.45 mM myo-inositol. 


\section{ACKNOWLEDGMENTS}

Dissertation presented by the first author to the Universidade Federal do Espírito Santo as part of the Requirements of the Programa de PósGraduação em Agricultura Tropical, to obtain a Master's Degree in Tropical Agriculture. The authors would like to thank Coordenação de Aperfeiçoamento de Pessoal de Nível Superior (CAPES), Conselho Nacional de Desenvolvimento Científico e Tecnológico (CNPq) and Fundação de Amparo à Pesquisa e Inovação do Espírito Santo (FAPES) for funding this work. The authors also thank owner of the farm "Vovô Délio", Edivaldo Permanhane, for providing the of 'Golden THB' papaya seeds.

\section{REFERENCES}

ABREU EFM AND ARAGÃO FJL. 2007. Isolation and characterization of a myo-inositol-1-phosphate synthase gene from yellow passion fruit (Passiflora edulis f. flavicarpa) expressed during seed development and environmental stress. Ann Bot 99: 285-292.

AGRAWAL V AND SARDAR PR. 2007. In vitro regeneration through somatic embryogenesis and organogenesis using cotyledons of Cassia angustifolia Vahl. In Vitro Cell Dev Biol Plant 43: 585-592.

ALMEIDA MV, SILVA AD, SOUZA MVN AND BENÍCIO AAA. 2003. A cascata dos fosfoinositídeos. Quim Nova 26: $105-111$

ALTAMURA MM, ROVERE FD, FATTORINI L, D'ANGELI S AND FALASCA G. 2016. Recent advances on genetic and physiological bases of in vitro somatic embryo formation. In: Germana MA and Lambardi M (Eds), In Vitro Embryogenesis Higher Plants. Humana Press 1359: 47-85.

ANANDAN R, PHAP PD, SOORIANATHASUNDARAM K, KUMAR N, THIRUGNANAKUMAR S, SUDHAKAR D AND BALASUBRAMANIAN P. 2010. Somatic embryogenesis in Carica papaya L. through zygotic embryo derived callus culture. Acta Hortic 851: 201-208.

ANANDAN R, SUDHAKARA D, BALASUBRAMANIANA P AND GUTIÉÝRREZ-MORAB A. 2012. In vitro somatic embryogenesis from suspension cultures of Carica papaya L. Sci Hortic 136: 43-49.

ASHTON AR AND ZIEGLER P. 1987. Lack of effect of the photosystem II based herbicides diuron and atrazine on growth of photoheterotrophic Chenopodium rubrum cells at concentrations inhibiting photoautotrophic growth of these cells. Plant Sci 51: 269-275.

BELMONTE MF, MACEY J, YEUNG EC AND STASOLLA C. 2005. The effect of osmoticum on ascorbate and glutathione metabolism during white spruce (Picea glauca) somatic embryo development. Plant Physiol Biochem 43: 337-346

BOLOURI-MOGHADDAM MR, ROY KL, XIANG L, ROLLAND F AND VAN DEN ENDE W. 2010. Sugar signalling and antioxidant network connections in plant cells. FEBS J 277: 2022-2037.

CARIMI F, TORTORICI MC, DE PASQUALE F AND CRESCIMANNO FG. 1998. Somatic embryogenesis and plant regeneration from undeveloped ovules and stigma/ style explants of sweet orange navel group [Citrus sinensis (L.) Osb.]. Plant Cell Tiss Org Cult 54(3): 183-189.

CASTILLO B, SMITH MAL AND YADAVA UL. 1998. Liquid system scale up of Carica papaya L. somatic embryogenesis. J Hortic Sci Biotech 73: 307-311.

CASTRO LM, MOURÃO FILHO FAA, MENDES BMJ AND MIYATA LY. 2010. Embriogênese somática a partir de calos de cultivares de laranja doce. Cienc Rur 40(8): 1831-1834.

CHETRI SK, KAPOOR H AND AGRAWAL V. 2016. Marked enhancement of sennoside bioactive compounds through precursor feeding in Cassia angustifolia Vahl and cloning of isochorismate synthase gene involved in its biosynthesis. Plant Cell Tiss Org Cult 124(2): 431-446.

CIPRIANO JLD, CRUZ ACF, MANCINI KC, SHIMILDT ER, LOPES JC, OTONI WC AND ALEXANDRE RS. 2018. Somatic embryogenesis in Carica papaya as affected by auxins and explants, and morphoanatomicalrelated aspects. An Acad Bras Cienc 90(1): 385-400.

CLARINDO WR, CARVALHO CR, ARAÚJO FS, ABREU IS AND OTONI WC. 2008. Recovering polyploid papaya in vitro regenerants as screened by flow cytometry. Plant Cell Tiss Org Cult 92: 207-214.

COUÉE I, SULMON C, GOUESBET G AND EL AMRANI A. 2006. Involvement of soluble sugars in reactive oxygen species balance and responses to oxidative stress in plants. J Exp Bot 57: 449-459.

CRUZ CD. 2016. Genes Software - extended and integrated with the R, Matlab and Selegen. Acta Sci Agron 38: 547 552.

DEVI BC AND NARMATHABAI V. 2011. Somatic embryogenesis in the medicinal legume Desmodium motorium (Houtt.) Merr. Plant Cell Tiss Org Cult 106: 409-418.

DIAS LLC, OTONI WC, BARROS RS, FLOH EIS, RIBEIRO DM AND CATARINA CS. 2010. Ethylene and polyamine interactions in morphogenesis of Passiflora cincinnata: effects of ethylene biosynthesis and action modulators, as well as ethylene scavengers. Plant Growth Regul 62: 9-19. 
DIX L AND VAN STADEN J. 1982. Auxin and gibberellinlike substances in coconut milk and malt extract. Plant Cell Tiss Org Cult 1: 239-245.

EVANS DE, LI C AND EGLINTON JK. 2009. The properties and genetics of barley malt starch degrading enzymes. In: Zhang G and Li C (Eds), Genetics and improvement of barley malt quality. Springer Berlin Heidelberg, p. 143189.

FAO - FOOD AND AGRICULTURE ORGANIZATION. 2012. Food and agricultural commodities production: papayas. Available in: http://faostat.fao.org/site/567/ default.aspx\#ancor. Acessed on March 10, 2014.

FELTRIN SEMENTES. 2009. Mamão THB segmento: Solo. Disponível em: http://www.sementesfeltrin.com. br/_uploads/pdf/InfoTecnicaP_231.pdf. Acesso em 21 de dezembro de 2013.

GREINER R, TURNER B, RICHARDSON A AND MULLANEY E. 2007. Phytate-degrading enzymes: regulation of synthesis in microorganisms and plants. In: Turner BL, Richardson AE and Mullaney EJ (Eds), Inositol phosphates: linking agriculture and the environment. CABI, Wallingford Oxfordshire, p. 78-96.

HALLAK R AND PEREIRA FILHO AJ. 2011. Metodologia para análise de desempenho de simulações de sistemas convectivos na região metropolitana de São Paulo com o modelo ARPS: sensibilidade a variações com os esquemas de advecção e assimilação de dados. Rev Bras Meteorol 26: 591-608.

HERINGER AS, VALE EM, BARROSO T, SANTACATARINA C AND SILVEIRA V. 2013. Polyethylene glycol effects on somatic embryogenesis of papaya hybrid UENF/CALIMAN 01 seeds. Theor Exp Plant Physiol 25: 116-124.

HIRAGA S, MINAKAWA H, TAKAHASHI K, TAKAHASHI R, HAJIKA M, HARADA K AND OHTSUBO N. 2007. Evaluation of somatic embryogenesis from immature cotyledons of Japanese soybean cultivars. Plant Biotech 24: 435-440.

HUSSAIN SS, RAO AQ, HUSNAIN T AND RIAZUDDIN S. 2009. Cotton somatic embryo morphology affects its conversion to plant. Biol Plant 53(2): 307-311.

ISAH T. 2016. Induction of somatic embryogenesis in woody plants. Acta Physiol Plant 38: 1-12.

JUMIN HB AND NITO N. 1996. Plant regeneration via somatic embryogenesis from protoplasts of Uganda cherry orange (Citropsis schweinfurthii). Plant Cell Rep 15: 754757.

JUNG K, KIM Y AND LEE G. 2011. Effect of different levels of malt extract on antinutrients, in vitro digestibilities and viscosity during fermentation of jeungpyun. Food Sci Biotech 20: 679-685.
KARNOVSKY MJ. 1965. A formaldehyde-glutaraldehyde fixative of high osmolality for use in electron microscopy. J Cell Biol 27: 137-138.

KELLMANN-S OPYLA W, LAHUTA LB, GIELWANOWSKA I AND GÓRECKI RJ. 2015. Soluble carbohydrates in developing and mature diaspores of polar Caryophyllaceae and Poaceae. Acta Physiol Plant 37: 1-13.

KIM MK, YOON KH AND LEE GH. 2010. Effects of enzyme treatment on the physicochemical properties of nonglutinous rice flour and effects of malt extract treatment on retrogradation extension of non-glutinous rice flour. $\mathrm{J}$ Korean Soc Appl Biol Chem 53: 798-802.

KOEHLER AD, CARVALHO CR, ABREU SS AND CLARINDO WR. 2013. Somatic embryogenesis from leaf explants of hermaphrodite Carica papaya L.: A new approach for clonal propagation. Afr J Biotechnol 12: 2386-2391.

KORBES AP AND DROSTE A. 2005. Carbon sources and polyethylene glycol on soybean somatic embryo conversion. Pesqui Agropecu Bras 40: 211-216.

MÁRQUEZ-MARTÍN B, SESMERO R, QUESADA MA, PLIEGO-ALFARO F AND SÁNCHEZ-ROMERO C. 2011. Water relations in culture media influence maturation of avocado somatic embryos. J Plant Physiol 168: 20282034.

MISHRA M, SHUKLA N AND CHANDRA R. 2010. Role of polyethylene glycol in maturation and germination of transformed somatic embryos of papaya (Carica papaya L.). Acta Hortic 851: 227-230.

MISHRA S, SANYAL I AND AMLA DV. 2012. Changes in protein pattern during different developmental stages of somatic embryos in chickpea. Biol Plant 56: 613-619.

MUILU-MÄKELÄ R, VUOSKU J, HAMBERG L, LATVAMÄENPÄÄ H, HÄGGMAN H AND SARJALA T. 2015. Osmotic stress affects polyamine homeostasis and phenolic content in proembryogenic liquid cell cultures of Scots pine. Plant Cell Tiss Org Cult 122: 709-726.

MURASHIGE T AND SKOOG F. 1962. A revised medium for rapid growth and bio-assays with tobacco tissue cultures. Physiol Plant 15: 473-496.

MURASHIGE T AND TUCKER DPH. 1969. Growth factor requirements of citrus tissue culture. Proceeding First International Citrus Symposium, Riverside 3: 1155-1161.

OLIVEIRA RP, MENDES BMJ AND TULMANN NETO A. 1994. Obtenção e cultura de calos nucelares de limão Cravo, tangerina Cleópatra e Poncirus trifoliata. Rev Bras Fisiol Veg 6: 115-119.

POSADA-PÉREZ L, MONTESINOS YP, GUERRA DG, DANIELS D AND GÓMEZ-KOSKY R. 2017. Complete germination of papaya (Carica papaya L. cv. 'Maradol Roja') somatic embryos using temporary immersion system type RITA $^{\circledR}$ and phloroglucinol in semi-solid culture medium. In Vitro Cell Dev Biol Plant 53: 505-513. 
POSADA-PÉREZ L, MONTESINOS YP, OLMEDO JG, RODRIGUEZ RB, SÁNCHEZ RR, MONTENEGRO ON, ESCRIBA RCR, DANIELS D AND GOMEZKOSKY R. 2016. Effect of phloroglucinol on rooting and in vitro acclimatization of papaya (Carica papaya $\mathrm{L}$. var. Maradol Roja). In Vitro Cell Dev Biol Plant 52: 196203.

QUINTAL SSR, VIANA AP, GONÇALVES LSA, PEREIRA MG AND AMARAL JÚNIOR AT. 2012. Divergência genética entre acessos de mamoeiro por meio de variáveis morfoagronômicas. Sem Ciên Agr 33: 131-142.

RAI MK, JAISWAL VS AND JAISWAL U. 2009. Effect of selected amino acids and polyethylene glycol on maturation and germination of somatic embryos of guava (Psidium guajava L.). Sci Hortic 121: 233-236.

RANCÉ IM, TIAN W, MATHEWS H, KOCHKO A, BEACHY RNAND FAUQUET C. 1994. Partial desiccation of mature embryo-derived calli, a simple treatment that dramatically enhances the regeneration ability of indica rice. Plant Cell Rep 13: 647-651.

REDEKAR NR, BIYASHEV RM, JENSEN RV, HELM RF, GRABAU EA AND MAROOF MAS. 2015. Genomewide transcriptome analyses of developing seeds from low and normal phytic acid soybean lines. BMC Genomics 16: $1-16$.

SANTOS KGBD, MARIATH JEDA, MOCO MCC AND ZANETTINI MHB. 2006. Somatic embryogenesis from immature cotyledons of soybean [Glycine $\max (\mathrm{L}$.) Merr.]: ontogeny of somatic embryos. Braz Arch Biol Techn 49: 49-55.

SEIFERT F, BÖSSOW S, KUMLEHN J, GNAD H AND SCHOLTEN S. 2016. Analysis of wheat microspore embryogenesis induction by transcriptome and small RNA sequencing using the highly responsive cultivar "Svilena". BMC Plant Biol 16: 1-16.

SHI J, WANG H, HAZEBROEK J, ERTL DS AND HARP T. 2005. The maize low-phytic acid 3 encodes a myoinositol kinase that plays a role in phytic acid biosynthesis in developing seeds. Plant J 42: 708-719.
SOUZA AP AND ESCOBEDO JF. 2013. Estimativas da radiação global incidente em superfícies inclinadas com base na razão de insolação. Rev Bras Ciên Agr 8: 483-491.

SOUZA AP, ESCOBEDO JF, DAL PAI A AND GOMES EM. 2011. Estimativas das componentes da radiação solar incidente em superfícies inclinadas baseadas na radiação global horizontal. Rev Bras Eng Agr Amb 15: 277-288.

STASOLLA C, ZYL LV, EGERTSDOTTER U, CRAIG D, LIU W AND SEDEROFF RR. 2003. Transcript profiles of stress-related genes in developing white spruce (Picea glauca) somatic embryos cultured with polyethylene glycol. Plant Sci 165: 719-729.

TROCH V, WERBROUCK S, GEELEN D AND LABEKE MV. 2009. Optimization of horse chestnut (Aesculus hippocastanum L.) somatic embryo conversion. Plant Cell Tiss Org Cult 98: 115-123.

VALE EM, HERINGER AS, BARROSO T, FERREIRA ATS, COSTA MN, PERALES JEA, SANTA-CATARINA C, SILVEIRA V AND FERREIRA ATS. 2014. Comparative proteomic analysis of somatic embryo maturation in Carica papaya L. Proteome Sci 12: 2-17.

VARDI A AND GALUN E. 1988. Recent advances in protoplast culture of horticultural crops: Citrus. Sci Hortic 37: 217-230.

VON ARNOLD S, SABALA I, BOZHKOV P, DYACHOK J AND FILONOVA L. 2002. Developmental pathways of somatic embryogenesis. Plant Cell Tiss Org Cult 69: 233 249.

WANG D, YAO W, SONG Y, LIU W AND WANG Z. 2012. Molecular characterization and expression of three galactinol synthase genes that confer stress tolerance in Salvia miltiorrhiza. J Plant Physiol 169: 1838-1848.

ZHANG S ET AL. 2016. Analysis of weighted co-regulatory networks in maize provides insights into new genes and regulatory mechanisms related to inositol phosphate metabolism. BMC Genomics 17: 1-17.

ZHUO C, WANG T, LU S, ZHAO Y, LI X AND GUO Z. 2013. A cold responsive galactinol synthase gene from Medicago falcata (MfGolS1) is induced by myo-inositol and confers multiple tolerances to abiotic stresses. Physiol Plant 149: 67-78. 